folk/ed. 2021; 27(2): 489-146

DOI: $10.22559 /$ folklor.1616

Araştırma makalesi/Research article

\title{
The Recurrence of an Indian Dream, Magic Seeds
}

\author{
Nükseden Bir Hint Rüyası, Magic Seeds
}

\section{Timuçin Buğra Edman* Hasan Boynukara** Hacer Gözen ${ }^{* * *}$}

\begin{abstract}
Magic Seeds is a work of fiction, but it also serves as a reflection of the real world, the history of India, where value judgments in a society return to their starting point only by reforming in accordance with the reconstruction of a given society. Willie, who is in search of identity and a home, finds the remedy in joining the guerrilla order. However, here, he fights through the shadow of the past, which he can never escape. The shadow of the past is the hierarchy itself, and this article explores the never-ending transformation of hierarchy, anarchism, and the search for order through the novel Magic Seeds. This article is a comparative study of the novel Magic Seeds, and history, the Naxalite movement in India from the 1960s

Geliş tarihi (Received): 16.05.2020- Kabul tarihi (Accepted): 24.03.2021

Assoc. Prof. Dr., Duzce University Faculty of Education Department of English Language Teaching.

** Prof. Dr., Namik Kemal University Faculty of Science and Letters English Language and Literature. hboynukara@

*** Dr., İsik University School of Foreign Languages. hacergozen@gmail.com. ORCID 0000-0001-5013-7804
\end{abstract} timucinbugraedman@duzce.edu.tr. ORCID 0000-0002-5103-4791 nku.edu.tr. ORCID 0000-0001-5121-9916 
until the early 2000s. Through the historical revolutionary Naxalite movement and a political association of the Marxist-Leninist Communist Party of India in West Bengal in 1960s, this study also reveals why an anarchic movement apparently returns to its starting point, and legs behind the decolonization or reconstruction of a society due to the deep-rooted and pre-structured hierarchy in a society by considering the terms humanization, dehumanization, hierarchy, cast system, anarchism, transformation and reconstruction.

Keywords: Magic Seeds, hierarchy, anarchism, transformation, reconstruction of a society

\section{$\ddot{\mathbf{O} z}$}

Magic Seeds, bir toplumun değer yargılarının sıfırlansa bile, o toplumun yeniden inşasında bu değer yargılarının sadece şekil değiştirerek başladıkları yere döndüğü kurgusal ama aynı zamanda gerçek dünyanın, Hindistan tarihinin bir yansımasıdır. Kimlik ve bir ev arayışında olan Willie, çareyi Gerilla düzenine katılmakta bulur. Ama burada aslında hiçbir zaman kaçamayacağı geçmişin gölgesiyle savaşmaktadır. Geçmişin gölgesi hiyerarşinin ta kendisidir ve bu makalede hiyerarşi, anarşizm ve düzen arayışı içindeki bitmeyen dönüşüm Magic Seeds adlı roman üzerinden incelenmektedir. Bu makale, kurgusal romanın (Magic Seeds) ve 1960'lı yıllardan 2000'li yılların başına kadar olan Hindistan'daki Naxalite hareketini anlatan tarihin karşılaştırmalı bir çalışmasıdır. Bu çalışma, romanın ve Hint tarihinin karşılaştırmalı analizini yaparak, toplumdaki köklü hiyerarşi nedeniyle, bir toplumu sömürüden kurtarmanın veya yeniden inşa etmenin ve topluma bağımsızlıklarını kazandırmanın neredeyse imkânsız olduğunu ortaya koymaktadır. Tarihi devrimci Naxalite hareketi ve 1960'lı yıllarda Batı Bengal bölgesindeki Hindistan'ın politik bir kuruluşu olan Marksist-Leninist Komünist Partisi incelemesi aracılığı ile bu çalışma aynı zamanda anarşik bir hareketin neden başlangıç noktasına geri döndüğünü ve neden toplumu sömürüden kurtarmakta veya yeniden inşa etmekte yetersiz kaldığını; insanlaştırma, insandışılaştırma, hiyerarşi, kast sistemi, anarşizm, dönüşüm ve yeniden inşa kavramları üzeninden açıklamaktadır. Bu anlamda, bu çalışma romana Hindistan tarihinin penceresinden bakar ve anarşiyle sömürüden kurtarma hareketlerinin aslında var olan eski hiyerarşik düzenin yeniden inşasının ötesine gidemediğini sergileyerek, geçmişteki hiyerarşinin her defasında sadece kendini yenilediğini ve amacının aksine geçmişte var olan sömürgeci güce ait bütün kuruluşların gücünü daha da sağlamlaştırdığını vurgular. Ayrıca, bu çalışma roman yazarı V. S. Naipaul'un Hindistan gerçeğini Magic Seeds romanına nasıl taşıdığını ortaya koymak amacındadır.

Anahtar sözcükler: Magic Seeds, hiyerarşi, anarşi, dönüşüm, toplumun yeniden inşası 


\section{Introduction}

Magic Seeds, one of the most fascinating novels of V.S. Naipaul, is a work in which there are many dilemmas surrounding the public's ability to adapt to the system, and the system to the public, only through revolution. It depicts a system that has come to a deadlock when the inequality of the people, combined with economic inequality, has brought this situation, perhaps because of the political leaders and their approach. Feasibly, if there was no authority over the people, there might exist a glimmer of hope for the system to work in a more adequate manner.

In such a turbulent atmosphere, the novel Magic Seeds is concerned with the painful struggle of the main character Willie who seems to be in search for a permanent home and identity by joining in a guerrilla movement in India after staying in Berlin without having what he had sought. When Willie learns from his sister Sarojini about the guerrilla movement in India, whose forerunner and leader is Kandapalli, he decides to assume a role with the aim of adding a notable meaning to his dull and hollow life. The basic tenet and purpose of the movement is to initiate a revolution and protect the rights of peasants and the masses, but it remains a movement in theory rather than in practice. Willie comes to an understanding that both his past and the present coexist simultaneously, but the current world has already wiped out the remnants of past. This is unlike his youth, where most of the Indians, including Willie, were more or less sweepers, taking dust and pigeonholing it elsewhere. Back in India, he realizes that his old comrades, who were once guerillas but are now bureaucrats, are totally disappointed by what they expected previously and what they have now. Therefore, it seems V.S. Naipaul juxtaposes the multicultural essence in Britain and the ambiguity in India that has somehow continued since India broke ties with Britain in 1947. However, this departure is not on the basis of a complete separation. Still today, India preserves the system that they have inherited from Britain, at least in terms of governmental management and on an institutional basis. On the other hand, the ongoing identity crisis presents a definite bilging of the ship. In other words, a continuous unrest is at hand in the homeland, India. Neither an ephemeral revolution nor political progress could possibly turn the lame system into a progressive one unless a positive anarchic takes place to change the hierarchical system. As Willie observes in England, only by turning your back to the past and your face to the future can it become possible to turn a new page, begin a new phase in the way of progression. Therefore, this article intends to present the transformation of hierarchy and anarchism and the search for order in V.S. Naipaul's Magic Seeds.

\section{The never-ending transformation of hierarchy, anarchism, and the search for order in Magic Seeds and the history of the Naxalite movement}

The 'Naxalite' movement was based on Marxism and Maoism and was initiated to put an end to the suffering and oppression of the peasantry. However, the 'Naxalite' movement failed due its incompatibility with the essence of India. Despite citing references to the 'Naxalite' movement, the primary purpose of Naipaul is to express the overlooked distress 
and exploitation of the silenced peasants in Magic Seeds (Zahiri, 2014: 168). More precisely, Naxalite is a revolutionary movement and a political association of the Marxist-Leninist Communist Party of India in West Bengal. It was established in 1969, and its policies were rigorously based on Maoist orders and Maoist discipline in China, which advocate building armed militant campsites in rural India and expanding the armed militant sites to surround urban areas (Jawaid, 1978: 56-75; see also Gupta, 2007; D’Mello, 2018; Samaddar, 2018). Naxalite policy was based on strategies such as the abolition of landlords, pawnbrokers, police, and denouncers who work for the police. The Naxalite movement also had a policy of annihilating those who would restrict Naxalites from settling refugees as villagers. Eventually, Naxalite policy would induce adherents to invade the political power in India. Despite the realization of such strategies by the Naxalites in driving out the landlords, pawnbrokers, and other suspicious people from the rural areas, the victory of the Naxalite movement was descending as their policies created the fear of terror or slaughter throughout the landlords, pawnbrokers, and others. The reason behind the decline of their victory was their failure to implement their plans and policies at the appropriate process and over the appropriate people. That is why the Naxalites could never realize their policies or plans (Jawaid, 1978: 73-75). Throughout the history of the Naxalite movement in India, from the 1960s until the early 2000s, many bloody assaults and all-out slaughters took place without the movement achieving any of its proposed purposes (see Jawaid, 1978; Gupta, 2007; D’Mello, 2018; Samaddar, 2018).

In the novel Magic Seeds, the narrative portrays the Naxalite movement as an illorganized and chaotic initiative which appears too utopian. Although the movement embarks on a struggle against a hierarchical social structure in Indian society, it then proceeds to embody hierarchy among its own members. The ambition to collapse hierarchy evolves into anarchy. As a result, Willie feels insecure and threatened and finally decides to give himself over to the police. While there is a strong possibility to transfuse a system to India that might stabilize conditions so that inequality can be equalized largely, Indian society has difficulty in decolonizing its British mindset.

Pierre-Joseph Proudhon defines decolonization as follows: "[E]very organization that exceeds its true limits and tends to invade or annex other organizations loses in strength what it gains in size, and moves toward dissolution" (quoted in Guérin, 1970: n.p. chpt. "Decolonization").

It is significant that as a city increases its population or its region, it draws closer to despotism and severity, and thereafter, eventuates in disruption. When this kind of city establishes exterior subordinate areas or colonies far away, these established exterior subordinate areas or colonies eventually will convert into new cities rather than being subordinate areas or colonies, and will associate with the mother city by federation only or not at all. If the new city manages to achieve a self-sufficient competence, this means it will proclaim its independence (Proudhon quoted in Guérin, 1970: n. p. chpt. "Decolonization").

According to Homi K. Bhabha, "decolonization had the dream of a 'Third World' of 
free, postcolonial nations firmly on its horizon" and the purpose of decolonization" was "to repossess land and territoriality in order to ensure the security of national polity and global equity" (quoted in Fanon, 2004: xi). Bhabha also asserts that "decolonization can be achieved only through the destruction of the 'compartmentalized' colonial system" (xiv-xv). Moreover, Fanon adds: "Decolonization, which sets out to change the order of the world, is clearly an agenda for total disorder ... The 'thing' colonized becomes a man through the very process of liberation. Decolonization, therefore, implies the urgent need to thoroughly challenge the colonial situation" (2-3; for "decolonizing the mind" see also Thiong'o, 1981; for decolonization in India see also Elst, 2005). On the other hand, during this process, it is very likely for people who are exposed to this radical change to be thrust from one personality to another. This is much like the case of Willie Chandran, who initially thought that revolution was the only way out given the troublesome state of his country. Nevertheless, after being imprisoned and succumbing to terrible agonies, he finally understood that this socalled revolution would never ever bring the total change for which they had been fighting.

In his book Pedagogy of the Oppressed, Paulo Freire adduces the terms 'humanization' and 'dehumanization,' which explicate how colonizers may regain their freedom and identity to decolonize:

"Within history, in concrete, objective contexts, both humanization and dehumanization are possibilities for a person as an uncompleted being conscious of their incompletion. But while both humanization and dehumanization are real alternatives, only the first is the people's vocation. This vocation is constantly negated, yet is affirmed by that vey negation" (2005: 43-44).

This vocation is frustrated via unfairness, inequity, profiteering, violation, brutality, and oppression. On the other hand, this vocation is advanced by the oppressed one's strong desire and hunger for independence and justice, and this vocation is also advanced by their endeavor to reclaim their demolished humanity. Dehumanization signifies both sides of oppression: the oppressor, who has stolen humanity, and the oppressed, 'whose humanity has been stolen.' Dehumanization is a destruction of the quest to be entirely human (Freire, 2005: 43-44; for the terms 'humanization' and 'dehumanization,' see also Thiong'o, 1981; Bhabha, 1990; Memmi, 1991).

As a precaution, Freire also underscores that if humans are dehumanized as a result of the exposure to oppression, which induces misery and pain, in this case, dehumanized people are not committed to the same practice of dehumanization. In the case that dehumanized people act in accordance with the oppressor through the progress of liberation, all of the endeavours they exert lag behind decolonization (2005: 67).

As Mikhail Bakunin states:

"It is necessary to abolish completely, both in principle and in fact, all that which is called political power; for, so long as political power exists, there will be ruler and ruled, masters and slaves, exploiters and exploited. Once abolished, political power should be replaced by an organization of productive forces and economic service" (Salvadori, 1968:144). 
Depending on Bakunin's statement, what Willie finds back in India is just the opposite. His former comrades have come into strong positions, but they seem to be slaves to power. Therefore, long expected change occurs only on the surface. The system persists, and only the names of the players change. Furthermore, the primary problem is that even if the Indians had gained their independence, they always tend to mimic the British and therefore the system of economic exploitation created by the British. In other words, Indians must generate an authentic system that is totally theirs, with less admiration for what they used to have, and with a greater inspiration towards what they are capable of. However, because the problem of mimicry has not ceased to be the main obstacle in front of the Indian people, it becomes more and more difficult to exit this vicious circle. It is indispensable here to more fully explain what 'mimicry' refers to in postcolonial theory:

"An increasingly important term in post-colonial theory, because it has come to describe the ambivalent relationship between colonizer and colonized. When colonial discourse encourages the colonized subject to 'mimic' the colonizer, by adopting the colonizer's cultural habits, assumptions, institutions and values, the result is never a simple reproduction of those traits. Rather, the result is a 'blurred copy' of the colonizer that can be quite threatening. This is because mimicry is never very far from mockery, since it can appear to parody whatever it mimics. Mimicry therefore locates a crack in the certainty of colonial dominance, an uncertainty in its control of the behaviour of the colonized" (Mambrol, 2016: n.p.).

Lord Macaulay's suggestion on colonial policies in India helps to portray what 'mimicry' is. Macaulay advocates that "the riches of European learning should be imparted by 'a class of interpreters between us and the millions whom we govern - a class of persons Indian in blood and colour, but English in tastes, opinions, in morals, and in intellect" (Macaulay, 1835, cited in Mambrol, 2016: n.p.). Another designation of 'mimicry' hails from Bhabha's approach: "The copying of the colonizing culture, behaviour, manners and values by the colonized contains both mockery and a certain 'menace', 'so that mimicry is at once resemblance and menace"” (Bhabha, quoted in Mambrol, 2016: n.p.). In Magic Seeds, because it focuses on the Naxalite Movement, which arose immediately after the 1947 revolution, Naipaul displays another mimicry, and especially a political mimicry, since the Naxalite Movement, which is akin to the Maoist revolution, has nothing to do with the Indian people at the stage of the 1947 revolution. Thus, guerillas were following a futile Maoist revolution that ended up being a cheap mimicry since, as we witness through Willie's eyes, the so-called revolution will bring only another repeat of the British system that they have been trying to eradicate.

Having defined some key terms, focusing on the incidents will hence be rendered more enlightening. The novel starts with Willie's stay in Germany, where his sister also lives. After sojourning in England and Africa, Willie, who was born in India, travels to Germany in order to make a fresh start. Nevertheless, he fails and plunges into a new start with the aim of finding a stable life and an identity free from crisis. He then decides to be a part of a guerrilla movement in his homeland of India. His sister, Sarojini, suggests that he return to India and 
find Joseph, who is one of the leaders of the movement in India. When Willie meets Joseph in a flat, Joseph says to him: "Primitive, they say, but I think that's where the Africans have the edge on us. They know who they are. We don't. There's a lot of talk here about ancient culture and so on, but when you ask them they can't tell you what it means" (Naipaul, 2004: 38). Joseph confesses that Africa and India have entirely different histories, memories and awareness, even though both are decolonized nations.

According to Joseph, Indians think that they possess a deep-rooted history, whose origins derive from the ancient times. However, they are not aware that the West has defined them, and their knowledge of the past is restricted to what the colonizers have informed them of and imposed upon them. In fact, India assumes the position of a colonizer after being colonized for many years by the British. Like the Stockholm Syndrome, Indians have a great admiration toward the British system and "Britishness." It is a process by which V.S. Naipaul defines a transformation, "Jamshed into Jimmy," in his quintessential article. ${ }^{1}$ Naipaul's severe criticism of Indians as it pertains to their imitation of the Western world, much like apes on one side and those seeking to restore a pure ancient cultural pattern on the other (King, 2003: 67-68), may be worth noting here. The narrative stresses that unlike Africans who admit their status as slaves, Indians desire to imitate Western values and strive to close their eyes to their present truth.

Naipaul defines Indians as passive, self-centered, too other worldly, corrupted, and far from self-evaluation through a rational and realistic lens and believes in the existence of "a caste system in which part of the population is considered subhuman, beneath notice and enslaved to such tasks as sweeping and taking away the excrement of others" (King, 2003: 65-66). Joseph draws attention to the existence of a caste system throughout the history of India, which persists even now:

"The serfs in the villages policed themselves. They were of various low castes, and there is no caste hatred greater than that of the low for the low, one subcaste for another. Some ran before and after the horses of their lords. Some did the scavenging. Some did the grave digging. Some offered their women. All of them referred to themselves as slaves. All of them were underfed" (Naipaul, 2004: 40).

The existence of such a caste system poses certain problems in the development of a collective soul and a united front in India. A wide range of religious beliefs, languages and cultures prevent India from enacting radical changes. Such a case lays the groundwork for the emergence of constant inner conflicts as a major component of the Indian nation.

For Indians, it was almost improbable to decolonize and gain their freedom, as the caste system formed the roots of their nations. In order to decolonize their self-being, it is essential for Indians to deconstruct all of their pre-structured orders and systems, such as institutions of centralization, law, justice, authority, and all of the foremost sources and foundations of power. In this section, to see why Indians fail at decolonizing their minds, it is crucial to divulge anarchism as a social movement that will enlighten the notion in India. 
According to Peter Kropotkin, anarchism owes its roots to the people's productive, visionary enterprise, which generated the entire association of the communal world in the past. Anarchism also owes its existence to a protest, that is to say, a revolt counter to exterior power. In Kropotkin's contemporary time, the similar significant and rebellious protests and revolutionary objection spawned anarchism, which substantially sparked socialism. Kropotkin adds: "Only that some of the socialists, having reached the negation of Capital and of our social organization based upon the exploitation of labor, went no further ... It attacks not only Capital, but also the main sources of the power of Capitalism" (Kropotkin, 2002: 5-6; for the term 'anarchism' see also Ward, 2004; Guérin, 1970).

As Ramnath states, "the word anarchism implies a set of assumptions and principles, a recurrent tendency or orientation-with the stress on movement in a direction, not a perfected condition-toward more dispersed and less concentrated power; less top-down hierarchy and more self-determination" (2012: 7). Anarchism also aids the decolonization period in India. In that sense, in the view of Indians, anarchy and decolonization lag behind their purpose, as Indians were much further behind in deconstructing all of the order and surrounding institutions designed to secure the power of colonizer and oppressor.

With this in mind, the scene makes more sense: Joseph points to his female servant in his house and mentions the impossibility of achieving a revolution due to peasants' physical incapacity and weakness: "Her village is full of people like her, very small, very thin. Cricket people, matchstick people. Their minds have gone after the centuries of malnourishment. Do you think you can make a revolution with her?" (Naipaul, 2004: 40). For Joseph, in addition to social problems and conflicts in society, there are also physical matters such as bodily power and fitness, the lack of which play a pivotal role in the failure of the guerrilla movement.

As soon as Willie joins in the movement, he realizes that its members come from different social strata, and he believes that his dreams are thwarted after what he witnesses there. The author recounts the following:

"During the day Willie thought, 'Kandapalli preached the Mass Line. Kandapalli wished the villagers and the poor to fight their own battles. I am not among the poor and the villagers in this camp. There has been some mistake. I have fallen among the wrong people. I have come to the wrong revolution. I don't like these faces. And yet I have to be with them. I have to get a message out to Sarojini or to Joseph. But I don't know how. I am completely in the hands of these people" (Naipaul, 2004: 50).

"Willie is disillusioned by the violent movement and cannot endorse the urban middle class intervention", and he believes that these townsmen "cannot be the custodians of the poor and demand justice for them" (Zahiri, 2014: 171-172; see also Karagoz and Bay, 2020). It is too late for Willie to discern that the peasants do not assume any role in the war, and those who actively participate in the movement generally belong to the middle class or are townsmen. The feelings of fear, insecurity and obscurity begin to exercise influence over him. Willie finds himself among people whom he cannot rely upon. He makes an effort to 
understand their background and get to know them better by analyzing their facial expressions and physiques. This process is described as follows:

"He could only try to read the faces and the physiques: the too-full, sensual mouth in some speaking of some kind of sexual perversion, the hard mean eyes in others, the bruised-seeming eyes of yet others that spoke of hard or abused childhoods and tormented adult lives. That was as far as he could read. Among these people seeking in various ways to revenge themselves on the world, he was among strangers" (Naipaul, 2004: 3).

What Willie grasps after studying the guerillas is that they experienced hardship, suffering and depression in the past, and that they took part in the revolution in order to make up for their crises by killing and using violence. They do not manifest any actual concern about the oppression and poverty of the peasants. Their focal points are their personal revenge and an escape from their previous lives.

In the novel, it is implicitly conveyed that there is a wide gap between the guerrillas and the peasants in terms of their outlook on life and their insights. For instance, one of the guerrillas states to Willie: “I also miss the jokes. In the movement you can't make jokes. And you can't make jokes with the peasants. They absolutely don't like it. Sometimes I feel they will kill you if they think you are teasing them" (Naipaul, 2004: 63). This corroborates the notion that the peasants have a different sense of humor and unique understanding of things, both of which probably have a bearing on the painful experiences they have lived through the ages. A sense of humor can be said to be related to comprehension, but it might also be associated with one's culture and experience. When one considers that the peasants have lived through exploitation, grief, oppression and great poverty for centuries, it comes as no surprise that they are not accustomed to jokes. They cannot distinguish jokes from seriousness and reality, as a member of the movement emphasizes: "You have always to say literally what you mean. If you are used to the other way of talking, it's not always easy" (Naipaul, 2004: 63). Because the guerillas have been kept away from amusement and fun as a result of their harsh living conditions, the man warns Willie about the peasants' tendency to comprehend every expression verbatim, without taking into account other figurative meanings and irony.

Willie is startled by the ways in which they are provided military training, which he believes will not prepare them for real fighting. The novel relates this mindset in the following way:

"Willie thought, 'But what will happen when battle is joined, when the other side attacks? We are not being trained for that at all. This is just the beginning of military theory. This is nothing. All these people will be good for is to fire a gun at someone who can't fire back. And that is really what they want" (Naipaul, 2004: 55-56).

Willie does not believe that the movement aims to train them so that they can succeed in defeating counter-forces. In the camp, they are provided very uncomplicated training and are taught to kill a person who is not armed. For Willie, this is not appropriate in a real fight, where enemies are armed and can fire back at them. As a result, training in the camp does not seem to be full-fledged and sufficiently realistic. 
Because the villages are situated near the forest and the camp of the movement is also set up in the bush, it becomes very difficult for the guerrillas to adjust themselves to a nearly primitive way of life in which they are deprived of the convenience of modern cities and their opportunities. This upheaval also stems from blurred demarcations among those who are situated at different levels under distinct conditions. Neither the guerrillas are real guerrillas, nor are the peasants real peasants. Naipaul displays a world that co-exists in another world, whereby he doesn't consider himself a part of an inferior culture but somehow hastens to bring a resolution to the scene, whereby Indians seem to be simply the sweepers who simply raise clouds of dust but change nothing within the frame of cultural amalgamation. It seems these people need a change in perception to free the bonds of their caste system, as well as western attitudes that have kept them blind for a long time. In that sense, "[a]narchism is obviously the representative of the first tendency - that is, of the creative, constructive power of the people themselves, which aimed at developing institutions of common law in order to protect them from the power-seeking minority" (Kropotkin, 2002: 3). Anarchism today seeks to build structures that will guarantee a free development of society using the same common ingenious power and productive enterprise, which is centered on modern science and technology. That is to say, Anarchists and Governmentalists have endured throughout history (Kropotkin, 2002: 3). One night, one of the sentries unknowingly declares a false alarm after interpreting the sound of an animal as an enemy who has crept into their area. The leader says: "The sentry made a mistake last night and gave us all a big fright. I don't think the sentry should be blamed. He is not used to the forest and wild animals..." (Naipaul, 2004: 54-55). This mistake attests to the case in which members of the movement can confuse an animal with an enemy, and vice versa. This would give rise to a fatal corollary for the guerrillas. Members of the movement are not real peasants and have no knowledge and awareness of their surroundings, which might prove to be a vexing issue in a fight against the enemies.

In a similar vein, Willie is depicted as exerting to adapt himself to the forest and village life where little creatures abound. He is instructed to wear "slippers" which will "protect him from scorpions and other dangerous creatures, but it was hard for Willie, too used to socks, to walk in slippers. For much of the time his bare heels slipped off the shiny leather and trod the ground" (Naipaul, 2004: 57). Walking among such animals with the fear of being stung is not an ordinary action for one who is an outsider in the village, since such animals are not found in cities. Additionally, walking in socks and shoes is eventually abandoned, and bare feet touch the ground. This is possibly not a typical habit to which a newcomer like Willie can easily habituate himself.

When Willie is taken by a boy to the camping area of the guerrilla movement, they pass through some villages in which Willie experiences real rural conditions in terms of food and shelter. It is depicted in the novel as follows:

"They halted at night in another village, and spent the night again in a hut with a calf and hens. They ate rice flakes. There was no tea, no coffee, no hot drink. The water they drank was dirty, from a muddy brook" (Naipaul, 2004: 49). 
The author hints at the truth of basic differences between cities and villages concerning daily needs and facilities. In the village, food may not be clean and hygienic, and housing conditions differ from those in a city in the sense that flats and hotels in cities or towns might be more luxurious. Meeting daily needs can require profound patience and strenuous effort for a townsman, owing primarily to the scarcity of materials.

Additionally, the author presents conflicts in the movement that concern the stance of fighters regarding the peasants and how the peasants should be treated. To illustrate, Einstein criticizes Kandapalli, who is the initiator of the movement across the country, as follows:

"The poison of Kandapalli's teaching is responsible for what has happened. The idea of organising the people through the people sounds pretty, and people abroad will applaud it. But we who know the reality know that the peasants have to be disciplined before they can become foot soldiers of the revolution. You have to rough them up a little bit... That's why I talk as I do. I never hide what I come from. There is no beauty in the peasant. That is Kandapalli's teaching. He is a man of a high caste, though he suppresses his caste suffix. He is wrong because this movement is not a movement of love. No revolution can be a movement of love. If you ask me, I will tell you that the peasants ought to be kept in pens" (Naipaul, 2004: 103-104).

Einstein endorses the idea that the peasants need to be educated by using violence and strict discipline in order to turn them into real fighters for the revolution. His critiques of Kandapalli's doctrine build on the lack of any precept that orders violent training for the peasants. For Einstein, because Kandapalli comes from a high caste, his attitude toward the peasants is predicated on nourishing false hopes, which represent unrealistic and imaginary convictions.

Ramachandra, one of the prominent fighters in the movement, complains a great deal about the peasants' reluctance to take possession of the land that the old landowners have left and to cultivate the soil. Referring to the response of the peasants to the abandoned land, he comments: "We will talk for two hours and they will appear to agree with you, but then at the end they will say again, 'It's not our land"' (Naipaul, 2004: 115). Ramachandra does not conceal his rage toward the peasants' long-standing inclination to bow to their present situation and not display any desire to break themselves of such a habit. He claims: "You can get them to clean out water tanks. You can get them to build roads. But you can't get them to take over land" (Naipaul, 2004: 115). He proposes that they do not possess any inner motivation to proceed to take action for the revolution, so they must be awakened by members of the revolution. He explains: "I begin to see why revolutions have to turn bloody. These people will begin to understand the revolution only when we start killing people. They will have no trouble understanding that" (Naipaul, 2004: 115). According to Ramachandra, the only means of prompting the peasants to join in the revolution and fight is through resorting to violence and killing some of them if they insist on remaining passive. Consequently, Ramachandra and Einstein are of the same opinion about the manner in which 
Kandapalli fails to emphasize educating the peasants by means of strict pressure and violence.

The narrative deftly portrays how the movement proceeds to be oriented toward a new stage in which some members' views on the method of revolution differ from the forerunner Kandapalli. The new stage signifies a chaotic milieu, which causes Willie to deeply regret his decision to participate in the movement. He observes that the movement has deviated from the aim of fighting on behalf of the peasants and has instead turned toward inter-group conflicts regarding Kandapalli's theoretical propositions of the revolution. Living in fear for his life, Willie sends a letter to Sarojini concerning the impending danger. Sarojini's reply is as follows:

I don't know whether Joseph is responsible or whether somebody else is responsible. The movement, as you know, has split, and what has happened is that you are among psychopaths. In every underground movement, and I mean every underground movement, there is an element of criminality. ..Some of the people around you are what is known in the movement as action men. That means they have killed, and are ready to kill again. They can be boastful and wild. The comfort is that you are all serving the same cause in the end, and the time may come one day when you may be able to cross over and join Kandapalli's people (Naipaul, 2004: 63-64) (Italics are original).

It seems that Sarojini does not become startled and takes it naturally that such revolutionary movements normally deviate from their aims and harbor blood-thirsty members. She suggests that Willie recoil from such murderous people and continue seeking supporters of Kandapalli.

When Ramachandra hears that there is a plan of attack against him and his comrades, he begins to suspect "the police," "Kandapalli's supporters," "men hired by that big farmer who wants to buy the land from the old feudal" or "villagers who have become tired of having" them "in their villages and want now to get rid of" them (Naipaul, 2004: 121). This may be regarded as an indication of the fact that feelings of suspicion and insecurity exercise control over the movement. The number of enemies or potential enemies increases over the course of events. Even the peasants, whose rights Ramchandra and other fighters aim to protect, become suspects and begin to turn into a target. The author insinuates that the chaotic atmosphere in the movement, where there is no sign of collective action, inevitably forces its members not to rely on any person or group. The urge to ensure personal security and escape from being caught by the police lead the guerillas to set other priorities aside.

The narrative accentuates occasions where recognized figures of the movement gather to talk about the course of the movement, as well as "the nature of the peasantry as compared with the nature of the urban proletariat (a favourite topic)" (Naipaul, 2004: 105). This means that members of the movement feel the need to classify even the oppressed masses as those in the city and those in the village. It is possibly imparted that there might be inconsistencies between the sufferings and the plight of these two different groups. The city is an intersection point in which a diversity of cultures and social classes can reside. It is also a location which encompasses a more modern life, and in which rapid changes can be observed on the basis of technology and social life. Meeting daily needs does not often seem to pose any problem 
for the proletariat. On the other hand, the peasants try to sustain their lives through the use of very limited resources. Sometimes, it may be really difficult to find even water and satisfy other basic needs. The village life also denotes the state of being a far cry from modern technological developments, rush and tumult that constitute a primary part of city life. Thus, the expectations of the urban proletariat and the peasantry naturally differ greatly from the viewpoint of their needs, problems and outlooks. This also becomes another factor that could lead the revolution into chaotic action and anarchy.

\section{Conclusion}

Because the novel illuminates V.S. Naipaul's paradigm on a similar axis of symmetry, that draws a line directly on the border of the occident and the orient, Naipaul tends to turn his face toward the "el imperio donde nunca se pone el sol."2 Magic Seeds creates an equilibrium of events, whilst neither the caste system nor the government allows a balanced population without an overarching hierarchy. Freeing the roots of people can only be possible through a rebellion that seeks to sever the connections of the rulers and the people of India, regardless of their economic status. However, the caste system, which has become a cultural value ever-ready and accepted by everyone, perpetuates the pyramid system that is upheld by peasants and laborers. On the other hand, because they were once colonized, Indians in turn tend to colonize others, repeating what was taught them by their forerunners. As the Naxalite Movement eventually ends up as a political mimicry, revolutions fail, and are Indians bumped into a cul-de-sac. Ephemeral changes will bring no good in the short term, other than willingly infusing the old empire's system back to India. Willie's transformation, which was very similar to India's so-called transformation, seems to rest on the surface. He has changed, time has altered his ideas, but still, at the core of his beliefs, Willie doesn't remodel himself as a better revolutionist as the past casts a shadow upon India: a silhouette of Empire. Since everything that can be done in order to get rid of the shadow of the past continues to turn the 'Indian Dream' into a nightmare, the best step that can be taken is to cast off and wake up from this nightmare and continue with a new, fresh Indian identity, separated from a caste system filled with segregation. For this, the existing system should be rejected by implementing a positive anarchist structure and a movement that is still suitable for Indian culture, but also through a structure that does not ignore equality or offer exclusive privileges. Unless this happens, like Naipaul's Willie, the character's changing name or occidental education will only provide a superficial progression, while the only change inside, very similar to Willie's occidental name, is actually the name of the system. Therefore, the only remaining possibility is to reject the entire system of India and to cast off all different classifications that derive from a great stigmatized hunchback: the unjust caste system. With an anarchist approach, it will be possible to remove all traces and hierarchical status before and after the colonial period of India in order to reach a certain level system and maintain whatever can be saved from a modernized India. 


\section{Endnotes}

1 “Jamshed into Jimmy.” New Statesman, January 25, 1963.

2 "The empire on which the sun never sets."

\section{Works cited}

Bhabha, H. K. (1990). Nation and narration. NY: Routledge Publishing.

D’Mello, B. (2018). India after Naxalbari: Unfinished history. New York: NYU Press.

Elst, K. (2005). Decolonizing the Hindu mind: Ideological development of Hindu revivalism. India: Rupa Press.

Fanon, F. (2004). The wretched of the earth. (Translated from the French by R. Philcox with commentary by J.-P. Sartre and Homi K. Bhabha) NY: Grove Press.

Freire, P. (2005). Pedagogy of the oppressed. (Translated by M. B. Ramos with an introduction by D. Macedo) NY: The Continuum International.

Guérin, D. (1970). Anarchism: From theory to practice. (M. Klopper, Trans.), (N. Chomsky, Introduction) NY: Monthly Review.

Gupta, D. K. (2007, August). The Naxalites and the Maoist movement in India: Birth, demise, and reincarnation. Democracy and Security, 3, 157-188.

Jawaid, S. (1978, September). The Naxalite movement in India: Origin and failure of the Maoist revolutionary strategy in West Bengal 1967 - 1971. A thesis of Master of Arts, Brock University.

Karagöz, C. and Bay, S. (2020). V. S. Naipaul'un Magic Seeds adlı romanında madunların sessizliği. Social Sciences Studies Journal, 6 (71), 4449-4459.

King, B. (2003). V. S. Naipaul. (2nd Ed.) New York: Palgrave Macmillan.

Kropotkin, P. (2002). Anarchism: A collection of revolutionary writings. New York: Dover.

Memmi, A. (1991). The colonizer and the colonized. (Introduction, J-P. Sartre; Afterword, S. G. Miller) Beacon.

Naipaul, V. S. (2004). Magic Seeds. New York and Toronto: Alfred A. Knopf.

Ramnath, M. (2012). Decolonizing anarchism: An anti-authoritarian history of India's Liberation Struggle. Edinburgh: AK.

Salvadori, M. (Editor). (1968). Modern socialism. UK: Macmillan.

Samaddar, R. (Ed.). (2018). From popular movements to rebellion: The Naxalite decade. NY: Routledge. Thiong'o, N. (1981). Decolonising the mind. The Politics of language in African literature. Zimbabwe: Zimbabwe Publishing House.

Ward, Colin. (2004). Anarchism: A very short introduction. Oxford: Oxford University.

Zahiri, A. (2014). Submerged idealism in V. S. Naipaul's Magic Seeds: An ambivalent Evolution? South Asian Review, 35(2), 163-175.

\section{Electronik resources}

Mambrol, N. (2016, April 10). Mimicry in postcolonial theory. Literary Theory and Criticism. Retrived on 20/12/2020 from https://literariness.org/2016/04/10/mimicry-in-postcolonial-theory.

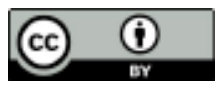

Bu eser Creative Commons Atıf 4.0 Uluslararası Lisansı ile lisanslanmıştır.

(This work is licensed under a Creative Commons Attribution 4.0 International License). 